Copyright (C) 2021 The Author/s

This work is licensed under a CC-BY 3.0 License

Peer review method: Double-Blind

Accepted: August 08, 2021

Published: September 21, 2021

Review article

DOI: https://doi.org/10.47305/JLIA21370250m

\title{
THE CONCEPT OF JUSTICE IN REFERENCE WITH PHILOSOPHIES OF PLATO AND ARISTOTLE: A CRITICAL STUDY
}

\author{
Sooraj Kumar Maurya \\ Ramanujan College, University of Delhi, New Delhi, India \\ ORCID iD: https://orcid.org/0000-0002-6974-5508 \\ sooraj.au998@gmail.com
}

\begin{abstract}
The concept of justice has been a constant issue since its conception. The Greeks also attempted to define justice. They have observed justice as goodness in deeds and so a virtue. In the Greek mind, fairness was an attribute of the spirit or soul, while injustice was a sin. Both Plato and Aristotle defined justice as kindness as well as a desire to follow the law. It alluded to the connection between rights and duties. In human interactions, justice was the pinnacle of excellence and the attitude that animates folks in the right fulfillment of their responsibilities. The development of harmony and peace in thinking and conduct was pre-eminently social. In the same way, Aristotle's and Plato's fairness are complementary; both philosophers seek to discover a concept of ability by which unity, harmony, virtue, and pleasure may be produced in a community. Despite this shared agreement, they are fundamentally different in many ways. In this paper, an attempt has been made by the author to discuss the similarities and dissimilarities in theories of justice propounded by Plato and Aristotle.
\end{abstract}

Keywords: Universal Justice; Particular Justice; Distributive Justice; Rectificatory Justice; Procedural Justice; Substantive Justice

\section{INTRODUCTION}

This paper is not a problem-solving piece, but rather the author has attempted to expand the ideological and conceptual understanding regarding the theories of justice proposed by Plato and Aristotle. In doing so, the author has tried to articulate and develop a better philosophical picture of theories proposed by Plato and Aristotle. Moreover, the author has attempted to compare and contrasts both theories of justice. And, it has been synthesized that these theories are still relevant and can be used as a moral toolbox to eradicate the widespread complex forms of injustices. The study uses the qualitative method of inquiry, such as the comparative, analytic, and critical methods. All three methods have been used to discuss the theories of justice given by Plato and Aristotle. 


\section{THE PLATO'S THEORY}

Plato has contributed to society in many ways, and one among those, which is considered as the finest accomplishment, can be credited to his theory of justice. Justice, according to Plato, is a property of the person, the human mind, or the soul. It may be comprehended through examining the human soul, its traits, and its characteristics. The Republic of Plato devotes the most attention to the idea of justice. He considers justice to be the factor that binds a community intact. The Republic deals with the relationship between people and the real concept of social existence. The primary task of this book Plato is to uphold the rule of law. The inability of rule of law would invariably lead to the disintegration of the whole civilization. The philosopher-king would take every precaution to ensure that fairness is established. That is a reason why the constitution is referred to as a 'treatise on justice'. Plato's aim in developing the theory of justice was to refute the sophists' false ideas. The progressive system is the pinnacle of morality, fairness, and idealism, and justice cannot be reduced to a secondary role in such a community (Maurya 2020, 274).

No matter it is the highest-ranking official in the region, the ultimate objective is one in which the contract of justice unites various social groups. The primary object of Plato's Republic is to have peace and stability, social order and security, as well as all the chances for social interaction that make up the necessities and facilities of civilized life (Aristotle 1980). Plato considered the qualities or characteristics of a healthy society. According to him, society is nice if it embraces the four Greek cardinal virtues. Such as wisdom, courage, temperance, and the last one is an outcome of these three i.e., justice. Plato asserts that every country has its qualities, and the Greeks believe in these four virtues (Dahl, 1991, 812). He then goes on to investigate the various virtues. Justice is the most significant and a by-product of these three virtues (Dahl 1991, 819).

Plato has constructed his society based on these three virtues of an individual. According to him, a society can only flourish if it has a well stratified and distinct social order based on these qualities. For instance, if there is a soldier, he must have emotion as a dominant trait in his character or personality, and befitting virtue related to this class of soldier will be courage. In the same way, the class of philosophers must know dominant traits, and befitting virtue related to this particular class would be wisdom. Likewise, a trader must have the appetite as a dominant trait in his character and the befitting virtue of this particular class would be temperance. And, if the classes of society are working in accordance with the dominant trait and virtues the society will automatically get the state of justice (Dahl 1991, 809).

R. L. Nettleship expands on Plato's definition of bravery, saying that courage is the defense of a correct judgment in all conditions, not only on the battleground. Plato often implies strong confidence and determination as he says bravery. Individuals are encouraged to combat inequality and irrationality as a result of their beliefs. Bravery 
creates fairness in this manner (Bhandari 2002, 44). Self-control is the next quality in a healthy society. Unusually, Plato also explained the principle of self-control. He claims that the human soul is divided into two parts: inferior and superior. Self-control entails the inferior portion becoming obedient to the dominant part (Bhandari 2002, 33).

In the same manner, there are superior and inferior groups in a province (Bhandari 2002, 5-54), and the latter should submit to the former. The inferior's obedience to the dominant is insufficient for the province's self-control to be realized.

The groups of the society are required to accept. The treaty's core concept is who will govern the province and who will follow. To put it another way, Plato wishes to stress that all law and obedience must be founded on consensus for there to be no complaint. Plato's self-control, whether in the sense of a province or an entity, is a kind of orchestra. To fulfill the environmental obligation is justice, according to Plato's philosophy. So every category and citizen can carry out their responsibilities without anyone interfering with the actions of others. Plato said in 'The Republic' that in the situation of people in general, every human should indeed be put to being used for which nature meant him, one to one job (Dunning 1966, 28-29), and that then each individual should do his work and become one and not that several; and the whole town would have been one and not much more. Plato wishes to assert that existence has endowed certain persons with physical strength while others have been endowed with intelligence and wisdom. Any man has been courageous as a result of it.

Normally, one individual is incompetent for the work of another. If we embrace this weather occurrence, we should anticipate a man to work with nature in some way. This is the fundamental concept of law. Plato claims that if this is accomplished, liberty will begin to flourish in culture. Plato examined the definition of justice from a broader viewpoint, and as a result, he stated that justice is fully relevant in society. This is what we call justice (Anderson 2010, 1-24). Plato has stated emphatically that this must be achieved in a successful state. Specialism is another term for Plato's philosophy of justice (Anderson 2010, 14).

From the perspective of specialism, analyzing Plato's philosophy of justice according to Barker, justice is specialization; it is merely the desire to perform one's station's responsibilities while avoiding interfering with the activities of yet another unit, as well as its habitats is thus in the view of any person who performs his duty in his assigned location (Garthoff 2018, 181-208). According to Plato's Republic, justice requires that every other person and doing his enterprise, and perhaps the only company, to which he is ideally suited. Thus according to Plato, meddling and intervention create tremendous inequality. Thus, he claims that fair deeds result in punishment, while unfair actions lead to injustice. It can be analyzed by the above discussion as to how Plato called for fairness to avoid civil strife and division within the various groups and persons (Epicurus 1997). He believed that if each group was involved in fulfilling its natural obligation, there would be little need for discontent. His conviction 
was that the lack of specialism was the primary source of public discord and that through specialism, personal aspirations for political office and interference with other people's roles would vanish.

Plato never used the term 'justice' only at the state-level but he was always eager to see justice following the human soul. He also did not offer the word any legal meaning. Justice is a quality, much as bravery, self-control, and intelligence. Spiritual excellence in the perfect society is made up of the 4 principles. This ethical honesty is, once again, a quality shared by both the person and the province. As a result, the rational type of justice is ethical honesty. Individuals and states are not two distinct bodies. Both need justice (Annas 1976, 147-148). Justice or ethical honesty, not any lawful act, binds the person and the region - Plato's philosophy of justice rules out the prospect of legislation interfering with justice.

Plato has discussed that the spirit consists of three elements: purpose, soul, as well as hunger (Annas 1976, 147). In comparison to these three components of spirit, morality is associated with justice (Annas 1976, 148). In the same manner, we may argue that the fairness of the society is linked to the province's justice against its people. The constraint that would be the first thing that comes to mind when thinking about justice is its architectural essence. Much as the architect's jurisdiction acts as a restriction on inferior artisans, curtailing their enthusiasm, constraining their reach, and restricting their independence in the context of the architecture (Hacker-Wright 2007, 82). As a whole, justice acts as a restriction on a person's power, preventing him from doing many items about which he has both the urge as well as the potential.

There are some principles or perfections in Plato's philosophy of the ideal world, and now one of them is justice. However, it takes on the function of an artist. In other words, it is architectonic in comparison to other achievements. The following is how Michael Foster has shown his point. A carpenter makes a door with a high level of skill. However, the door's quality cannot be measured in isolation (Stace 1962, 320). When considering and evaluating the architecture and beauty of the house, the other parts of the structure must be taken into account. The door's architecture and dimensions must complement the building's other characteristics. This does not work for a carpenter; it is the responsibility of the builder. An architect's ability is not limited to a single unit, but it can be seen in all of them. Justice, according to Plato, serves as an architect. It functions as a command center for the individual's abilities, justice is not either a spiritual good or a human virtue; it often has political significance. It is an attribute that allows an individual to interact with other people, and this interaction shapes human culture, which is the focus of political science. Justice instills in each of us the ability to exercise self-control. It deters many people from engaging in behaviors that are detrimental to those in society. As a result, self-control is central in every political culture. An analyst made the following statement when discussing the law. For Plato, "justice is both a part of human nature and the connection that binds men with each other in the province" 
(Pogge 1994, 23). It is the same attribute that makes a person successful as well as social. This concept is Plato's democratic philosophy's first and most important concept. Sophists acknowledged justice's political importance, but not its moral value, that is, its spiritual goodness. That was a major disadvantage for the Sophists. According to the Sophists, justice or virtue was necessary for the establishment of political life. Plato did not approve of the Sophists' reluctance to recognize it as a human value. We can conclude that Plato's definition of justice is a complete and complete philosophy through this perspective.

\section{THE ARISTOTLE'S THEORY}

The essential principle of fairness pervades much of Greek political thinking. It is a conceptual idea that is impossible to describe in concrete terms, and various philosophers see it distinctly. However, according to Aristotle, there are two sorts of justice: general or universal and individual or particular justice (Ross 2009, 82 (1030a)). The former corresponds to following the rules to remain moral. In other words, Aristotle asserts that the state of lawfulness is called justice. According to Aristotle, happiness is the highest of all goods that is attainable, provided that may be perceived in different ways and manners with the different human minds. In Nicomachean Ethics, Aristotle distinguishes particular justice further in two types: distributive justice and corrective or punitive justice (Wayper 1954, 16). In his own words, "the just as the fair and equal: divided into distributive and rectificatory justice" (Ross 2009, 82 (1030a). According to distributive justice, the province should separate or share products and resources among people based on ability. Thus, corrective justice is split into two categories: voluntary transactions (civil law) and forced transactions (criminal law) (Ross 2009, 84 (1030a)).

To the above forms of justice, Aristotle applied economic and aggregate justice (Ross 2009, 83 (1030a)). This mode of justice, according to Aristotle, is the most effective rule for preventing revolutions since it trusts in the correct and proportional distribution of positions, honors, goods, and resources as a resident of the community. The majority of this justice is dealing with political rights. Any political organization, according to Aristotle, must have its distributive justice.

On the other hand, he opposed both egalitarian and oligarchic criteria of justice. He is allowing only the noblest to be appointed to positions of power based on their greatest sacrifices to humanity since noble citizens are small (Nielsen 1979, 5). Aristotle argued that the majority of the workplaces could be reserved for a select few (Nielsen $1979,5)$. Aristotle's philosophy of universal justice is quite interesting to be followed. The ideas such as the rule of law, equality before the law, and lawfulness were worthy of being by the mindset of individuals and states from ancient to modern times. Some thinkers may disagree with this thought. But, the deviation from this was arbitrary that 
was directed through some morally as well as legally impermissible policies and laws for nullifying or impairing the effects of equality. When it comes to particular justice, Aristotle appears to signify the kind of justice as a morally permissible and desirable distribution of commensurable goods, disadvantages, and benefits among ordinary people. From this discussion, it can be said particular justice is a system of norms unlike the commonality of general justice, which is responsible for integrating the society as a whole. Consequently, Aristotle has classified justice into two types namely; distributive justice and rectificatory justice. In his own words, "the just as the fair and equal: divided into distributive and rectificatory justice" (Ross 2009, 82).

Moreover, Aristotle's concept of particular justice has two strains. The first one is distributive justice, which is based on the philosophy that everyone should be given his due concerning the contributions to the authority. In other words, distributive justice appeals that a just distribution of consumable goods should be required in the state to ensure justice (Ross 2009, 82). This is the reason; the concept of distributive justice is always understood in this way, 'treating equals equally and un-equals unequally which means that an individual's right, duty, and reward should be in proportion to his merit and contribution to the state. Hence, according to this view of justice, the proportionate things just mean just and proportionate both are synonymous with each other. It is also an intermediate status between too large and too small or too much and too little (Ross $2009,85)$. It is mandatory to mention that the distribution is not arbitrary and blindfolded. Agent must have to take into account several particulars such as what is his or her share in proportion to his or her unequal worth or merit of an individual. According to the visualized ratio the distribution would take place. This mode of distribution takes place according to the geometrical proportion (Ross 2009, P. 84). Along with this, sometimes distributions take place in society according to the individual concerned.

The second type of particular justice is commutative or rectificatory or corrective justice (Ross 2009, 86). This type of justice is required in the case where one person performs some actions against other in such a manner that the agent gains and the victims suffer. Applying the core idea of this kind of justice is the best way to solve these unequal gains and suffers. There is a dire need to take back the morally impermissible benefits of the agent and returns them to the victims. Hence, by punishing the agent and compensating the victims, equality is restored (Ross 2009, 86). It is needed to be motioned that restorative justice does not demand or look into the status of an individual in the die course of awarding penalty or compensation but instead it has to be taken into account the nature of disadvantages caused to victims and benefits gained by agents (Ross 2009, 86). Thus, in this process, the individual's status is not taken into account. For this reason, justice follows the law of arithmetic proportion. 


\section{A COMPARISON IN VARIOUS FIELDS}

Philosophy

Plato held the belief that ideas had a basic, perfect nature, which led to his idealistic theory. Aristotle argued that fundamental types did not have to be attached to any idea or phenomenon and that each example of an idea or phenomenon had to be examined separately. Aristotelian empiricism is the product of this perspective. Plato believed that logical tests and inference would suffice to 'demonstrate' an idea or determine an object's attributes, but Aristotle disagreed, preferring direct observation and practice (Bertrand 1961, 185-201). Plato preferred inferential thinking to deductive reasoning in philosophy, while Aristotle preferred deductive reasoning.

Opinions, according to Aristotle and Plato, are equivalent to sensations (Moravcsik 1979, 24). Unlike Plato, who claimed that the perceptions could deceive a human, Aristotle claimed that the senses were necessary for properly determining truth. Plato's allusion to the cave is a good illustration of this distinction. To him, the universe was like a tunnel, where all one could see were shadows cast by the outside sun, and feelings were the only truth (Moravcsik 1979, 24). According to the Aristotelian approach, the natural alternative is to exit the cave and personally observe what is throwing light and shadows instead of focusing entirely on implicit or inner impressions.

Political Theory

The Republic of Plato puts forth a philosophy of justice: a philosophy of morality and a philosophy of politics. Plato has set a philosophy of political justice to further the ethical debate, drawing a parallel between the three sections of the mind, purpose, spirit, including desire, and the three classes of an ideal society: rulers, soldiers, and producers (Roochnik 1986, 301). The three sections of the just state, like the three parts of the just entity (Roochnik 1986, 295-310), exercise their duties following the other parts. The rulers are aware of not just the state's good but, most importantly, the good itself, as a result of years of intensive preparation to read them for their leadership position. The kings, according to Plato, must simply live and communal property, without personal land and sometimes sharing intimate partners. Both children born to rulers and other groups will be checked, with those who demonstrated the greatest talent and morality being accepted to ruler-ship learning (Roochnik 1986, 302).

'The Republic' of Plato is illustrious for its proclamation that only thinkers can preside over and its resistance to populism or administer by the populace. It generally symbolizes the opinions of the ancient Socrates, whose evaluation of Athens' democratic system may have supplied to his conviction in addition to implementation for irreverence and erstwhile offenses in three hundred and ninety-nine. Plato projected 
in considerable depth an amalgam system mingling aspects of both 'Monarchy and Democracy' in one of his last books, 'The Laws'. Scholars differ about whether the commandment is evidence that Plato lost his opinion on the magnitude of independence or if he was in point of creating substantive forgo cause of individual earth's shortcomings. As per the above standpoint, Plato's perfect humanity, or utopia, stayed the democracy, while the laws imitated the maximum that could be prepared in realistic conditions.

Aristotle is notable in political science for finding that person is a political being, which means that human beings essentially silhouette political civilizations. Even so, individuals cannot endure devoid of the prop up of civilization and the crucial aspiration of civilizations to cultivate well-being. Aristotle is also memorized for constructing a category of administration figures to recommend an avant-garde conception of democracy that was never commonly adopted.

Provinces, as per Aristotle, maybe categorized stood on the numeral of administrators as well as the desires they rule. Monarchy is where solitary individuals administer in the best welfare of each and everyone; dictatorship is when one individual governs in his own best comfort (Aristotle 1980, Book V). Aristocracy is controlled by a privileged group in the interests of all; oligarchy is rule by a privileged group in the interests of itself (Aristotle 1980, Book V). Polity is controlled by the mainstream in the welfare of every single 'democratic system' governed by a community of its comfort, which is called 'mob rule'. Monarchy is the highest system of administration in standard, and aristocracy is the second-best (Aristotle 1980, Book V). Though, the polity is the improved model as monarchy as well as aristocracy frequently distribute into hegemony in addition to oligarchy, respectively. Plato believed that to create an ideal system of governance, individuals could subsume their desires to those of society. His Republic depicted a utopian world in which each of the three groups (philosophers, soldiers, and workers) had a part to play, and the government was left in the care of the 'philosopher rulers', who was considered the fittest for the job (Morrison 2001, 1-24). The tone and point of view are that of an aristocracy caring for the less competent. Yet, without the Spartan oligarchy against which Plato battled, the Republic will take a more philosophical and much less martial course.

The town was Aristotle's core political entity, which took priority over the house, which assumed priority over the citizen. According to Aristotle, man is a political animal by birth and cannot escape political problems (Aristotle 1980, Book V). In his opinion, politics is more like an individual than a system (Weber 2000, 73). The polis aims to establish a place where its citizens can live a decent life and conduct beautiful deeds rather than provide justice or economic prosperity. Despite rejecting utopian solutions and large-scale structures (like states or kingdoms), Aristotle became the first political scientist, studying political dynamics to devise changes. 
The detection of contentment was the core concern of morality for Plato and Aristotle, as it was for most prehistoric moral philosophers. They did not articulate a happy rational situation when they supposed 'happiness' (the Standard English version of the Greek word ' $\varepsilon \dot{\delta} \delta \alpha u$ ovía' or 'eudemonia), but quite a vigorous human existence or existence of a person thriving. Virtue was the way by which peace was attained. As a result, ancient ethicists usually focused on 3 (three) queries: a) what constitutes a decent or prosperous person's existence? b) What qualities are required to accomplish it? and c) how does one attain such qualities? (Aristotle 1980, Book V).

Plato's early conversations cover a wide range of topics, including the essence of traditional principles like bravery, piety, and temperance, as well as more basic issues like whether morality may be learned. Socrates (Plato's teacher) is conversing with ostensibly knowledgeable people and the odd star, often exposing their meanings as insufficient. While Socrates claims ignorance and does not give his concepts, he implies that morality is a type of intelligence (Santas 1985, 223-45). Conscientious conduct (or the intention to behave justly) derives inexorably from such awareness, a viewpoint shared by the traditional Socrates, as according to Aristotle.

Socrates moves ahead to a belief of justice as a status of the spirit in Plato's later discussion, which is construed to articulate his outlooks. The just or righteous human, according to that job, is someone whose spirit is in equilibrium, with each one of its three components, "reason, spirit, and appetite" (Annas 1976, 147-148), desiring what is correct and right for it furthermore acting within prescribed bounds. The reason, indeed, figures out and wishes the person's benefit and the high-quality in specific. Nevertheless, such knowledge of the form of the positive can only be gained by years of study in discursive and other sciences, which the Republic often defines as an instructional curriculum. The evaluation depends on the end which it produces (Annas 1976, 147-148).

Contentment, for Aristotle, is not only a situation of the intellect but also a kind of proper procedure. He believed that the most important aspect of a healthy human existence is logic, which is a uniquely human practice. As a result, virtuous living is the moral practice of strength led by qualities (Fredev 2012, 367-390). Aristotle accepted philosophical and pragmatic or spiritual values, like courage and restraint, and intellectual virtues such as intelligence and knowledge. The latter types of virtue are usually thought of as a compromise between two extremes. According to Aristotle's 'Nicomachean Ethics', contentment is the pursuit of spiritual reflection in an individual who has spent a lifetime cultivating all of the academic and spiritual qualities. According to 'Eudemian Ethics', contentment is the practice of spiritual qualities in the political arena, while some philosophical and spiritual values are assumed. 
When it refers to morality, the relation between Socrates, Plato, and Aristotle is most apparent. In his insistence that intelligence is quality in itself, though, Plato was Socratic.

This implies that doing the correct thing to do would inevitably contribute to performing the right thing; this meant that morality might be learned through telling others right from wrong, good from the bad. According to Aristotle, knowing what was correct was not enough; one had to want to behave properly, in essence, to form the practice of doing well (Aristotle 1980, Book V).

Knowledge is the fundamental virtue, according to Socrates and Plato, and with it, one may consolidate all qualities into a whole. Aristotle argued that knowledge was admirable, but reaching goodness did not guarantee the unity (acquisition) of all virtues. Wisdom, according to Aristotle, was a task that could only be accomplished by effort and that unless an individual wanted to consider as well as behave properly, certain qualities would appear elusive (Aristotle 1980, Book V).

Socrates argued that pleasure could be found without goodness, but it was a foundation and bestial pleasure. Plato said that goodness was necessary for pleasure and that 'moral luck' did not exist to bestow incentives (Hampton 1993, 135-65). Aristotle held that goodness was appropriate for pleasure but inadequate in itself and that a good individual required acceptable social structures to experience satisfaction and happiness. It is worth remembering that during Plato's and Socrates' lifespan, Greek opinions on these subjects were more akin to Aristotle's than it is to Plato's or Socrates'.

Science

Plato's and several other Greek thinkers' contributions to science were overshadowed by Aristotle's. Plato wrote regarding physics, geometry, and mathematics, but his ideas were more exploratory than practical. A few of his works deal with genetics and physics, but only a handful of them contributed to the state of science at the moment.

Aristotle, on either hand, is regarded as one of the earliest genuine scientists, along with very few others. To study the cosmos and make hypotheses based on his observations, he developed an early prototype of the scientific process. His approach has evolved, but the overall mechanism has remained the same. In algebra, physics, and geometry, he introduced novel principles, but much of his study was more like variations or interpretations of emerging theories than discoveries. His zoology studies, including botany, prompted him to describe all forms of life, a project that lasted decades and served as the foundation of biology. Even though Aristotle's category scheme has been modified, much of his methodology is still used today in phraseology. His astronomical discourses called for stars apart from the earth, but they stayed geocentric, a concept Copernicus would later debunk. 
Aristotle introduced modern theories and discoveries to various areas of science, like medicine and geology, and although many of his concepts were later abandoned, they helped to open up fresh avenues of research for others to pursue.

Forms

The significant distinction, which can be observed between Plato and Aristotle, is in their concepts related to realities. According to Plato, the world of forms is the real world, which is related to the sense-independent idea only. So any attribute or kind corresponds to a type that is its complete exemplar or ideal kind. The qualities "beautiful and black refer to the types of beautiful and black, respectively, while the kinds of horse and triangle conform to the types of horse and triangle" (Drydyk 2012, 23-38).

When it 'engages' in the ways that refer to certain products or types, a component has the characteristics it has or corresponds to the type it corresponds to (Drydyk 2012, 23-38). Stuff is a magnificent black horse since it engages in the Magnificent, the Black, and the Horse; a thing is a big red triangle since it engages in the Large, the Red, and the Triangle; and so forth.

Types, according to Plato, are hypothetical structures that reside outside of time and space. As a result, they can only be known by the imagination, not through sense perception. Furthermore, since the Types are perpetual, they have a greater level of reality than objects in the universe, which are modifiable and constantly come into or out of being. Plato's mission in philosophy is to explore the essence of the Types, the only true truth, and their interrelationships by justification, resulting in an interpretation of the most basic Kind, the Better or the One.

Aristotle sacked Plato's belief of Shapes, but not the explanation of the figure itself. Things, as per Aristotle, do not happen separately of belongings; each type is a type of something else. A thing's considerable nature is the type of which it is assigned, for which it will be of a separate kind or eventually disappear entirely (Hacker-Wright 2007, 449-473). 'Black Beauty is a horse' ascribes a significant shape, horse, to a specific object, the animal Black Beauty, and Black Beauty does not operate without such a type. In contrast to substantive types, unplanned forms can be lost or acquired without affecting a thing's intrinsic essence. 'Black Beauty is black' ascribes to that same animal an unintentional shape, blackness, which may shift color (somebody would draw him) without losing his identity. Not only are significant and unintentional types not formed, but they are also not permanent. They are either incorporated into a thing at the time of manufacture or obtained later, like certain unintended types. 


\section{MODERN EVALUATION}

Although Plato and Aristotle are synonymous with theory and the pinnacle of Greek civilization, their activities are still not examined at desirable certainty. Most of what they said has been dismissed or ignored in favor of modern knowledge and ideas. See the video below for an explanation of a philosophy advocated by Aristotle and Plato that is no longer deemed legitimate. It concerns Plato and Aristotle's views on oppression.

Aristotle was seen as a barrier to scientific advancement by scholars and scientists since his activities were considered so comprehensive that no one questioned them. The use of Aristotle's activities as 'the ultimate authority' on several topics hampered genuine experimental methods (Friedman 1987, 92). This flaw is not attributable to Aristotle but rather to the way his works were used. Aristotle is known as 'the First Teacher' by Islamic academics, and much of his retrieved studies may have been lost if not for Arabic versions of the actual Greek discourses. Plato and Aristotle may be more beginning posts than nodes on analytical routes these days, but many people nevertheless read their works. Aristotle was inspired by Plato, much as Socrates influenced Plato. However, following their demise, each man's presence spread in various directions. Centered on his relations to Socrates and Aristotle and the existence of his books, which were used until his college collapsed in 529 A.D.; his activities were then replicated across Europe. Plato became the dominant Greek philosopher (Bloomfield 2012, 46-64). Plato's works were compulsory reading in classical education for decades. 'The Republic' was the main text on political philosophy until the nineteenth century, praised not just for its opinions but also it is graceful writing.

Throughout the Middle Ages, Aristotle and his works were the foundation for both theology and research. In theology, Aristotelian ethics served as the foundation for St. Thomas Aquinas' works, which shaped Christian ideas about free will and morality (Bloomfield 2012, 51). Until the XVI century, when Renaissance thinking questioned and gradually replaced most of Aristotle's empirical data, they have deemed the last word of science. Despite this, Aristotle's observational method focused on evaluation, theory, and direct practice (research) is a minimum part of the foundation for experimental practice in almost any area of science. 


\section{CONCLUSION}

To sum up, it can be said, that Plato has given an ideological or philosophical concept of justice, which is rested on the human soul and its dominant traits. Moreover, he has been a champion of class structure based on the dominant traits in the human soul (Annas 1976, 307-21). For, instance, philosophers having the knowledge, soldiers having the courage, and the working class having appetite as their dominant traits or virtues. This very idea of class structure has been questioned from a variety of perspectives from various thinkers. He promulgated the philosophy of speciality as a prerequisite for justice and peace. However, it is very disheartening to observe that Plato did not discuss anything about the current situation of his territory. For instance, in his own time, Plato observed the conflicts which are therein. Despite the fact, he did not analyze or ever said on the disputes or controversies among the representatives of the same party or between groups of the same dominant traits or virtues. Even, in India, a long battle is fought so far due to class or caste structure. Plato does not involve himself or ever tried to philosophize these crucial things to settle them (Annas 1976, 307-21). This can be regarded as the most significant drawback of Plato. He should have provided provisions for the resolution of these disagreements caused by the formation of class structure. Looking at the current changing dimensions of governance and changing in the attitudes towards the human constitution, it can be formulated that the co-existence of different classes in the same societies can only be seen, if all groups of individual traits and virtues will exercise self-control and stick to their assigned duties and supposed obligations. Justice can never be done through self-control (Maurya 2021, 824). So, justice can be an outcome of following duties according to the stages and aspects of human life and existence. If an individual does not ever attempt to practice, it can become a challenge and, it will lead to the society into an unintended struggle and conflicts among the individuals out there (Maurya 2020, 3938-3949). This is the reason; Plato has been observed as the philosopher who muddled the line between religious and legal commitments by blurring the contrast between them.

It is very interesting to note that Plato's concept of justice is rested more on the moral picture of the human constitution, which makes Plato not be accepted universally by modern thinkers (Annas 1976, 307-21). For instance, the social order based on the class structure would lead to the subordination of certain classes to another. It is because; by the passage of time, virtues or traits got into hierarchical structure too, likewise, wisdom got superiority over other two virtues, which indirectly led to the social-classes into an unavoidable emergence of hierarchy in the social-classes. Consequently, some classes of the society got dominance over others (Maurya 2020, 227-234). Then, the world witnessed the dominant class and oppressed class of the society and, it paves a better way to exploitations and discrimination. This article has put many points on which both agree and disagree. 
Plato has a different perspective to get the ideal state, likewise, Aristotle. But, it is important to note that this was the time when the thought process and philosophy were being shaped by these two great philosophers. Plato has attempted to get his ideal world through discussion on the human constitution and its dominant traits and virtues. And, he asserts that if society will be based on by looking at these characteristics of the human soul, harmony and development will not be too far to attain (Annas 1976, 307-21). But, modern perspectives pay less attention to this idealistic theory of justice proposed by Plato. Here comes the role of Aristotle, he has talked about justice in a very approachable and practical way. Like, when Aristotle asserts that general or universal justice means to act lawfully or conduct following law. In other words, it can be said that justice is a state of lawfulness that means everyone should be treated equally (Aristotle 1980, Book V). Aristotle discusses particular justice, which is further divided into two sorts; the first one, which has been already discussed above in the paper, i.e., the concept of distributive justice asserts that treating equals equally and un-equals unequally.

The second type of particular justice is commutative or rectificatory or corrective or remedial justice (Aristotle 1980, Book V). This sort of justice is needed when it is observed that in the relationships, an individual does an action in such a way that the other one gets harm (Aristotle 1980, Book V). It means, in this sort of justice, one person harms the other one. Interestingly, the concept of justice in Aristotle's philosophy also accepts that all the material and non-material structures have the only ultimate goal that is the fullest realization and actualization of the real happiness of human beings. For this reason, all the socio-economic and political structures should be molded in the way that they are meant to the realization of real happiness in their lives. Thus, it can be mentioned that justice is the core idea of Aristotle's philosophy that has the goal of the full-fledged development of society. A just society is that type of community where all the individuals are living in harmony with equality and amity (Maurya 2020, 99). The wealthy class's rent-seeking and the weak class's annexation pace are what propel manufacturing cycles in the Aristotelian economy. Since it recognizes trade-offs between the political impact of democratic government and vertical development methods, the Aristotelian economy's regular substitution of the dominant party contributes to higher levels of state productivity. Plato has taken away the freedom of the man to feel inside his direction. Human identification is impossible to maintain in the overwhelming structure of society (Maurya 2018, 402-412).

Interestingly, the concept of justice in Aristotle's philosophy also accepts that all the material and non-material structures have the only ultimate goal that is the fullest realization and actualization of the real happiness of human beings. For this reason, all the socio-economic and political structures should be molded in the way that they are meant to the realization of real happiness in their lives (Aristotle 1980, Book V). 
Thus, it can be asserted that justice is the core idea of Aristotle's philosophy that has the goal of the full-fledged development of society. A just society is that type of community where all the individuals are living in harmony with equality and amity. From the discussion of Aristotle's and Plato's theory of justice, it is clear as a crystal that justice can take any of the discussed forms and sometimes more than the discussed numbers by the socio-economic, geographical, and historical backgrounds of the separate entity in which the concept of justice is being applied (Aristotle 1980, Book V). Despite varied forms in the various fabrics of the world, there is a common element running through these variations of the use that is justice is aimed at ensuring the common interest in entire individuals (Aristotle 1980, Book V). For instance, in Aristotle's and Plato's discussion of justice the central theme of their focus was to show the path to the attainment of the well-being of the whole society theory of social justice applied to the basic institutional structure of a modern liberal state. 


\section{REFERENCES}

1. Anderson, Elizabeth. 2010. "The Fundamental Disagreement between Luck Egalitarians and Relational Egalitarians," Canadian Journal of Philosophy (Supplemental Volume), 36: 1-24.

2. Annas, J. 1976. "Plato's Republic and Feminism," Philosophy, 51: 307-21.

3. Aristotle. 1980. The Nicomachean Ethics, Translated by Commentaries and Glossary by Hippocrates G. Apostle, D. Redial Publishing, London, Book E, 5.

4. Bloomfield, Paul. 2012. "Justice as a Self-Regarding Virtue," Philosophy and Phenomenological Research, 82(1): 46-64.

5. Bhandari, D.R. 2002. Reprint History of European Political Philosophy, Bangalore, Bappco, the Bangalore Press, pp. 5-54.

6. Dahl, N. 1991. "Plato's Defense of Justice," in Philosophy and Phenomenological Research, 51(4), 809-834. doi:10.2307/2108183.

7. Drydyk, J. 2012. "A Capability Approach to Justice as a Virtue," Ethical Theory and Moral Practice, 15 (1): 23-38.

8. Dunning, W.A. 1966. A History of Political Theories-Ancient and Medieval, Allahabad, Copyright, Vol. 1, pp. 28-29.

9. Epicurus. 1997. "Principle Doctrines," in B. Inwood and L. Gerson (eds.) Hellenistic Philosophy, Indianapolis: Hackett Publishing.

10. Friedman, Marilyn. 1987. "Beyond Caring: The De-Moralization of Gender," Canadian Journal of Philosophy (Supplemental Volume), 13: 87-110.

11. Foot, Philippa. 1978. Virtues and Vices, Berkeley: University of California Press.

12. Frede, D. 2012. "Forms, Functions, and Structure in Plato", in R. Patterson, V. Karasmanis and A. Hermann (eds.), Presocratics \& Plato, Las Vegas: Parmenides Publishing, 367-390.

13. Garthoff, Jon. 2018. "The Dialectical Activity of Becoming Just," in LeBar 2018, 181-208.

14. Hacker-Wright, John. 2007. "Moral Status in Virtue Ethics," Philosophy: The Journal of the Royal Institute of Philosophy, 82(321): 449-473.

15. Maurya, Sooraj Kumar. 2020. Onto Nature and Forms of Affirmative Action," International Journal of Social Science, Innovation and Educational Technologies, 1:03, 272-280. https://doi.org/10.5281/zenodo.3977172.

16. Maurya, Sooraj Kumar. 2020. Affirmative Action: A Movement to Attain Gender Equality. Journal of Critical Reviews, 7 (18), 227-234. doi:10.31838/jcr.07.18.34.

17. Maurya, Sooraj Kumar. 2021. Roots, Routes, and Remedies of Gender Discrimination: An Ethical Discourse," Psychology and Education Journal, 57(8), 820-834.

18. Maurya, Sooraj Kumar. 2018. A Critique of John Kekes' Arguments of Affirmative Action. ZENITH International Journal of Multidisciplinary Research, 8(9), 402-412. 
19. Maurya, Sooraj Kumar. 2020. A Reply to Luois P. Pojman's Article "The case Against Affirmative Action". Conatus - Journal of Philosophy, 5(2), 87-113 Doi: $.12681 /$ cjp.23660.

20. Maurya, Sooraj Kumar. 2020. Does Gender Discrimination Rest on a Mistake?. Journal of Talent Development and Excellence, 12(2s), 3938-3949.

21. Moravcsik, J. M. E. 1979. "Forms, Nature and the Good in the Philebus," Phronesis, 24: 81-104.

22. Morrison, D. 2001. "The Happiness of the City and the Happiness of the Individual in Plato's Republic," Ancient Philosophy, 21: 1-24.

23. Nielsen, Kai. 1979. "Radical Egalitarian Justice: Justice as Equality" (called "Equality"). Social Theory and Practice, Vol. 5, No. 2.

24. Ross. W. D. (Tr), 2009. Aristotle's The Nicomachean Ethics, Revised with an Introduction and Notes by Lesley Brown, Oxford University Press, Oxford.

25. Russell, Bertrand. 1961. History of Western Philosophy, pp.185-201.

26. Roochnik, D. L. 1986. "Plato's Use of the Techne-Analogy" Journal of the History of Philosophy, 24: 295-310.

27. Stace, Walter T. 1962. A Critical History of Greek Philosophy, London, Macmillan, p. 320.

28. Sharif, M.M. 2001. A History of Muslim Philosophy, Delhi, Adam Publishers, Vol. 1, pp. 98-104.

29. Santas, G. 1985. "Two Theories of the Good in Plato's Republic," Archiv für Geschichte der Philosophie, 57: 223-45.

30. Sabin, G.H. 1949. A History of Political Theory. $3^{\text {rd }}$ edition, New York: Henry Holt and Co. p. 52.

31. Thomas, Pogge. 1994. "An Egalitarian Law of Peoples" (called "Egalitarian"). Philosophy and Public Affairs, Vol. 23, No. 3.

32. Weber, Alfred. 2000. History of Philosophy, Indian, Translated by Frank. Thilly, India, Surjeet Publication, $2^{\text {nd }}$ Reprint, p. 73. 